\title{
Analysis of Emulsified Renewable Fuel Injector in Burner Combustion: An Overview
}

\author{
Mirnah Suardi ${ }^{1, a}$, Norazwan Azman ${ }^{1}$, Dahrum Samsudin ${ }^{1}$, Norani Mansor ${ }^{1}$, \\ Amir Khalid ${ }^{1, b}$
}

\begin{abstract}
${ }^{1}$ Combustion Research Group (CRG), Centre for Energy and Industrial Environment Studies (CEIES), Universiti Tun Hussein Onn Malaysia, Parit Raja, Batu Pahat, 86400 Johor, Malaysia. amirnahsuardi@yahoo.com, bamirk@uthm.edu.my
\end{abstract}

Key Words: Emulsified Biodiesel, Renewable Fuel, Rapid Mixing, Mixture Formation, Combustion Process, Emissions, Flame

\begin{abstract}
The use of energy and natural resources being increase due to the growth of economy and world population. One of the natural resources is being consumed heavily is diesel for transportation and burner combustion. However, the major product results from the combustions of diesel are NOx and PM emissions. This review paper focuses on the influences of the emulsified renewable biodiesel fuel such as crude palm oil and waste cooking oil with the concept fuel-air-water internally rapid mixing injector for the open burner system. Water is introduced directly into the combustion field. The concept of rapid mixing from biodiesel and water are controlling of the combustion process in order to minimize the emissions. The water content in the emulsified biodiesel fuels effectively in the reduction of NOx emissions especially the high blending biodiesel. Moreover, emulsion technology significantly reduced particulate matter (PM) emissions as compared to the standard biodiesel fuel combustion. The parameters include equivalent ratio, water content in biodieselwater, and spray characteristics such as spray penetration, spray angle and spray area.
\end{abstract}

\section{Introduction}

As the environment pollution and diminishing supply of fossil fuels are the key factors the search of alternative sources of energy. Biodiesel now is the best choice for consumers and can occupy a great volume of the world's fuel sector. Biodiesel, as an alternative fuel of diesel, is described as fatty acid methyl or ethyl esters from vegetable oils or animal fats. It is renewable, biodegradable and oxygenated. Many researches had been concluded that biodiesel can reduce greenhouse gas emission [1]. In addition, the properties of biodiesel are similar to diesel fuels, but variation in fuel viscosity of biodiesel will cause poor atomization of the diesel engine as well as causing the clogging of the injector [6-8]. Some method had been used to decrease the viscosity of biodiesel like preheating the biodiesel and blending with lighter fuels such as diesel [13-18]. The researchers had studied that the performance of internal combustion engine fuel with preheated biodiesel like palm oil and the result is better because produce a better combustion and less deposits [2].

\section{Experimental setup}

The biodiesel used to be CPO and WCO biodiesel, which blended from Universiti Tun Hussein Onn Malaysia (UTHM) Automotive Laboratory and the particular of the tested fuel are detailed in Table 1 and Table 2. The injector is equipped with one air compressor and two electrical pumps. Air flow rates and fuel flow rates are controlled by control valve and a voltage regulator respectively. Figure 1 shows the setup of the experiment consists of an injector which has 8 holes with $1 \mathrm{~mm}$ diameter, the characteristic of injector is shown in Table 3[21]. Fuel is initially rapidly mixed with fuel-water-air will then pumped by the fuel pump to inject, afterwards the injector sprays the mixtures out with very fine droplets [1-3][9]. 
Table 1: Properties of CPO at ambient temperature $\left(45^{\circ} \mathrm{C}\right)$

\begin{tabular}{|c|c|c|c|c|}
\hline \multirow{2}{*}{ Fuel Type } & \multicolumn{4}{|c|}{ Properties } \\
\cline { 2 - 5 } & Density $\left(\mathrm{g} / \mathrm{cm}^{3}\right)$ & $\begin{array}{c}\text { Kinematic Viscosity } \\
\text { (cP) }\end{array}$ & Flashpoint $\left({ }^{\circ} \mathrm{C}\right)$ & $\begin{array}{c}\text { Water Content } \\
(\mathrm{ppm})\end{array}$ \\
\hline STD & 0.833736 & 3 & 80 & 79.6 \\
\hline B5 & 0.837048 & 3 & 91.5 & 120.1 \\
\hline B10 & 0.837664 & 2.9 & 92 & 158.6 \\
\hline B15 & 0.840428 & 3 & 93.5 & 219 \\
\hline B20 & 0.841172 & 3.1 & 94.5 & 294.7 \\
\hline B25 & 0.841716 & 3 & 97 & 363.3 \\
\hline B30 & 0.845852 & 3.2 & 97.5 & 397.1 \\
\hline B35 & 0.844816 & 3.4 & 99.5 & 426.9 \\
\hline B40 & 0.848236 & 3.2 & 100 & 558 \\
\hline
\end{tabular}

Table 2: Properties of WCO at ambient temperature $\left(45^{\circ} \mathrm{C}\right)$

\begin{tabular}{|l|c|}
\hline Parameter & Value \\
\hline Viscosity at $40^{\circ} \mathrm{C}(\mathrm{mm} 2 / \mathrm{s})$ & 47.66 \\
\hline Volume $(\mathrm{kg} / \mathrm{m} 3)$ at $15^{\circ} \mathrm{C}$ & 903 \\
\hline Flash Point $\left({ }^{\circ} \mathrm{C}\right)$ & 310 \\
\hline Free Fatty Acid $(\%)$ & 1.6 \\
\hline Acid Number $(\mathrm{mg} \mathrm{KOH} / \mathrm{g}$ Oil) & 3.2 \\
\hline Saponification Value $(\mathrm{mg} \mathrm{KOH} / \mathrm{g}$ Oil $)$ & 182 \\
\hline Water Content $(\%)$ & 0.6 \\
\hline
\end{tabular}

The camera aperture was set to f5.6, the shutter speed is at $1 / 80 \mathrm{Sec}$ for the spray image. The spray characteristic which includes penetration length and spray angle is an analysis, only one hole from the nozzle will be analyzed. Few set of spray image which from different flow rates and water content being taken to be compared. This study is keeping the injection air pressure at 0.35 bar and ambient density of $300 \mathrm{~K}$, all the operating condition and equipment specification are summarized in Table 3 [21].

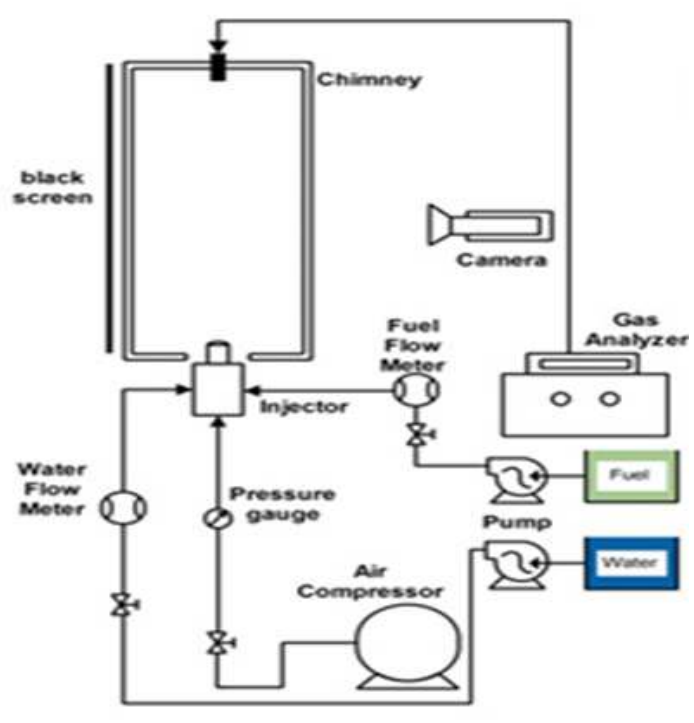

Figure 1: Schematic Diagram of experimental setup
Table 3: Experimental Condition

\begin{tabular}{|c|c|c|}
\hline \multirow[t]{3}{*}{ Air Compressor } & Model & PUMA XN2040 \\
\hline & Capacity, L/min & 200 \\
\hline & Pressure, $\mathrm{kg} / \mathrm{cm}^{2}$ & 8 \\
\hline \multirow[t]{3}{*}{ Washer Pump } & Voltage, V & 12 \\
\hline & Pressure, bar & 3 \\
\hline & Flow rate, $\mathrm{L} / \mathrm{Hr}$ & 7.2 \\
\hline \multirow[t]{3}{*}{ Fuel Pump } & Model & CNY-3805 \\
\hline & Pressure, bar & 3 \\
\hline & Flow rate, $\mathrm{L} / \mathrm{Hr}$ & 115 \\
\hline \multirow[t]{2}{*}{ DC Voltage Regulator } & Model & $\begin{array}{c}\text { Teletron TC- } \\
1206 \mathrm{~A}\end{array}$ \\
\hline & Current, A & $64(\max )$ \\
\hline \multirow[t]{5}{*}{ Operating condition } & Air Pressure, bar & 0.1 \\
\hline & Air Density, $\mathrm{kg} / \mathrm{m}^{3}$ & 1.16 \\
\hline & $\begin{array}{l}\text { Ambient Temperature, } \\
\mathrm{K}\end{array}$ & 300 \\
\hline & Water Percentage & $0-15 \%$ \\
\hline & Equivalence ratio & $0.6-1.4$ \\
\hline
\end{tabular}

\section{Result and Discussion}

An effect of the biodiesel on mixture formation was firstly investigated. The time indicate in the images is referring to the time start of injection[5][21]. Figure 2 and Figure 3 shows the spray formation of $\mathrm{W} 0, \mathrm{~W} 5, \mathrm{~W} 10$ and $\mathrm{W} 15$ in equivalent ratio 0.6 (lean), 1.0 (stoichiometric), and 1.4 (rich). The interval between each image taken is $0.03 \mathrm{~s}$ for every set. The spray of biodiesel fuel is sprayed upward from the injector when the supply mixtures are pumped into the injector, as vary with time, the volume of spray increases and it's drawn by the ventilation system [6][9-11]. As observed from the images, the spray is starting to expand at the time 0.06 second for all types of water content and equivalent ratio, thus it can be seen that after time $0.06 \mathrm{~s}$ the overall diesel spray is becoming thicker. Furthermore, the penetration length shows an increasing trend with equivalent ratio for each type of water content, while the spray angles remain unchanged. The increment of equivalent ratio of 0.6 to 1.4. This indicates that the concentration of biodiesel in the mixture increases. Hence the spray area is affected by the penetration length only.

Figure 6 shows the flame developments of crude palm oil with different water contents, as can observe from the figure, at an equivalent ratio of 1.0 (stoichiometric), the combustion can occur at 
this point for all fuels, but for W0 the flame is brighter and its flame height is higher than those diesel fuels that mixed with water.

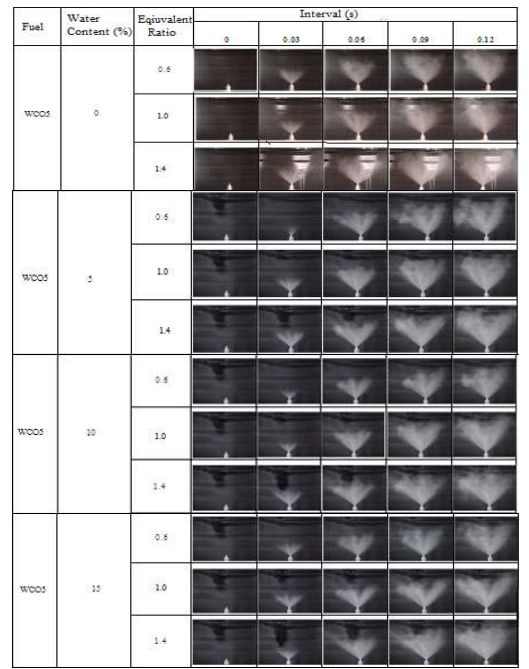

Figure 2: Mixture Formation for Biodiesel from WCO fuel

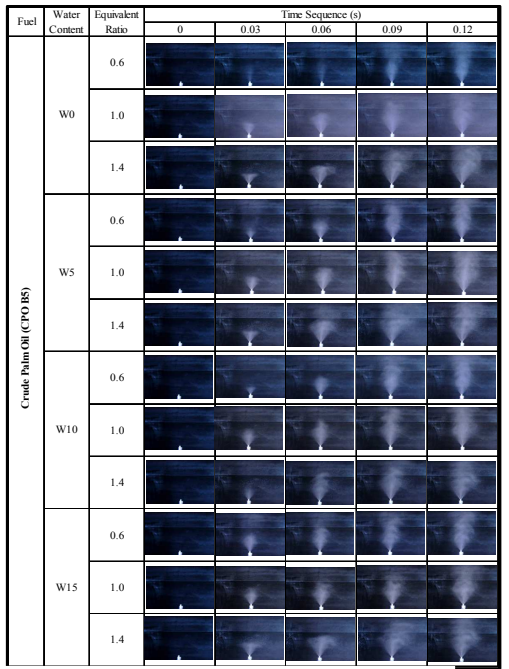

Figure 3: Mixture Formation for Biodiesel from $\mathrm{CPO}$ fuel

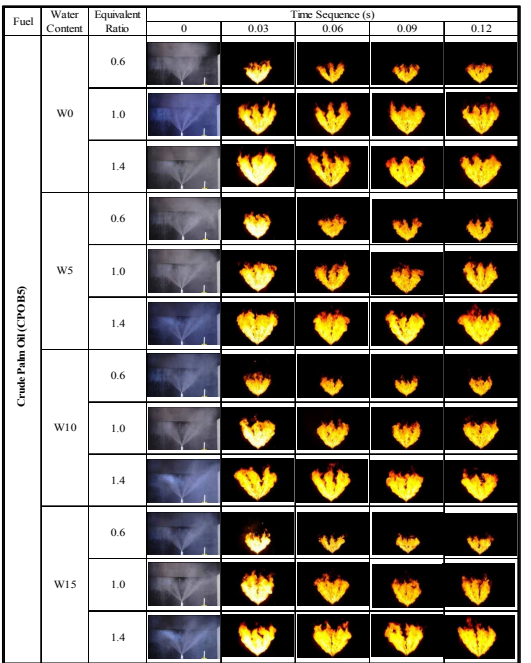

Figure 6: Biodiesel Flame Developement from CPO fuel

The biodiesel mixed with some water contents seem like having a lower flame height. It can be seen that for an equivalent ratio of 1.4 (rich) the flame height of $\mathrm{W} 0$ also higher than other diesel flames which due to inactive combustion that will lead high gas temperature occur[5]. Other than that, the flame area that produced from an equivalent ratio of 1.4 for all water contents have a larger flame area compared to other equivalent ratio. This is the point where the rich combustion takes place.

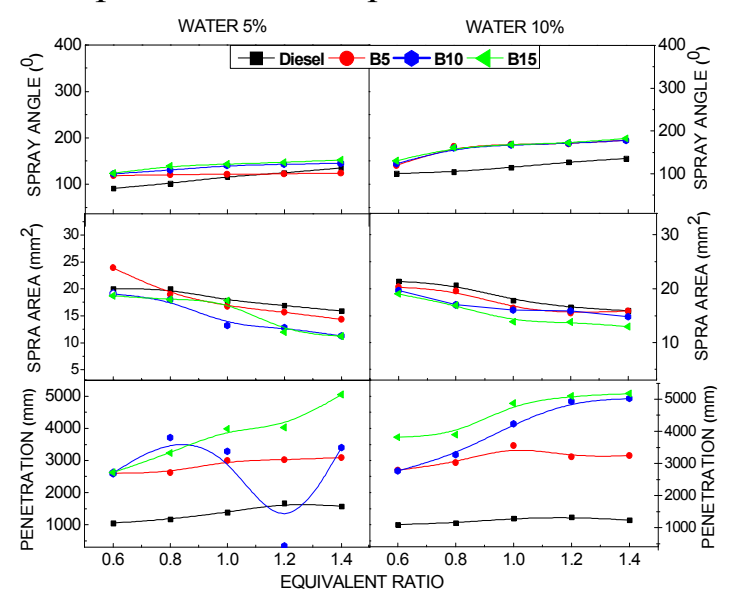

Figure 4: Effect of mixture formation derive from $\mathrm{CPO}$ fuel

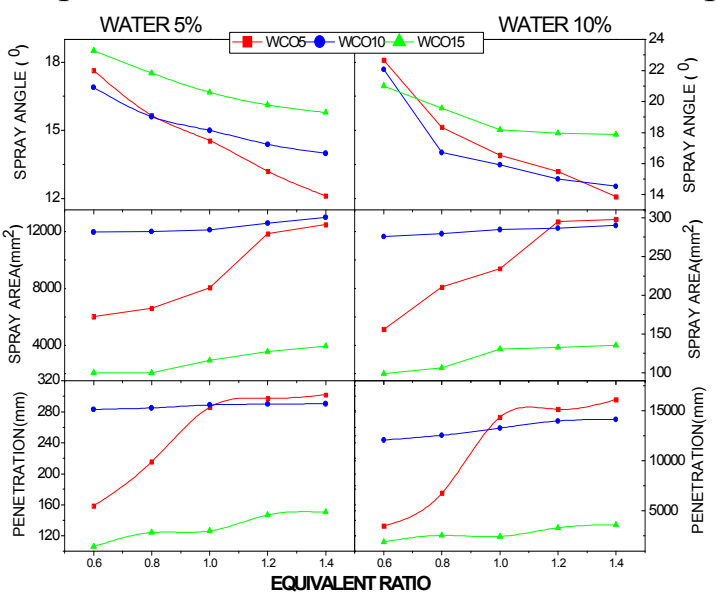

Figure 5: Effect of mixture formation derive from WCO fuel

Figure 4 and Figure $\supset$ shows the graph of mixture tormation which is penetration length, spray angle and spray area against equivalent ratio for water content of W0 to W15. From the figure, the penetration length is increasing with the equivalent ratio for different water content. At the same time, W15 has the highest penetration length among other water content due to the viscosity of W15 is the highest, which the penetration length is directly proportional to the viscosity [4-5]. W0, which is the pure biodiesel fuel, has the lowest penetration length with lowest viscosity[25-28]. The viscosity of the mixtures is affected by the water content, as the water content of the mixture increases, the viscosity also increase [8][21]. Therefore, it proves that the spray angle is inversely proportional to the viscosity as viscosity increase, the spray angle decreases.

\section{Conclusion}

In this research, a fundamental study on the emulsified renewable fuel injector process and burning process was carried out using a burner system. High water content in the mixtures will result in 
longer penetration length and smaller spray angle. Penetration length is contributing in spray area, where longer the length will produce the larger area. An equivalent ratio will give effect increase the penetration length as the equivalent ratio increase. In addition, flow rate makes the color intensity of spray increases with the increment of equivalent ratio, more fuel is being injected and hence the concentration of diesel fuel in the mixtures increases. The larger flame area is produced by a higher equivalent ratio, which the spray contains more fuel particles that makes the combustion process easy to take place.

\section{Acknowledgements}

The author also would like to thank the Ministry of Higher Education, Malaysia for supporting this research under Research Acculturation Grant Scheme (RAGS) Vot. R024 and Exploratory Research Grant Scheme (ERGS) vote. E032.

\section{References}

[1] Y. Kidoguchi, T. Yatsufusa, and D. Nakagawa, "Improvement of Emissions and Burning Limits in Burner Combustion using an Injector on the Concept of Fuel-water Internally Rapid Mixing," in European Combustion Meeting, 2011.

[2] Amir Khalid, N.Tamaldin, M. Jaat, M. F. M. Ali, B. Manshoor, Izzuddin Zaman, "Impacts of biodiesel storage duration on fuel properties and emissions", Procedia Engineering, volume 68, 2013, Pages 225 - 230, Elsevier, 2013, DOI: 10.1016/j.proeng.2013.12.172.

[3] T. Yatsufusa, T. Kumura, Y. Nakagawa, and Y. Kidoguchi, "Advantage of Using WaterEmulsified Fuel on Combustion and Emission Characteristics," in European Combustion Meeting, 2009, pp. 2-7.

[4] Ing, T.C., Mohammed Rafiq, A.K., Azli, Y., Syahrullail, S., 2012. The Effect of Temperature on the Tribological Behavior of RBD Palm Stearin. Tribology Transactions, Volume 55, Issue 5, Pages 539-548.

[5] Hafis, S.M., Ridzuan, M.J.M., Farahana, R.N., Ayob, A., Syahrullail, S., 2013. Paraffinic mineral oil lubrication for cold forward extrusion: Effect of lubricant quantity and friction, Tribology International, Volume 60, Pages 111-115.

[6] Amir Khalid, " Effect of Ambient Temperature and Oxygen Concentration on Ignition and Combustion Process of Diesel Spray". Asian Journal of Scientific Research 6(3),pp.434-444, 2013.

[7] W. C. M. Sekaran, "Transient State Fuel Injection - A New Concept with Different Fuel Combinations," in Interdisciplinary Research and Development, 2011, no. June, pp. 461-467

[8] Amir Khalid, S. H. Amirnordin, L. Lambosi, B. Manshoor, M. F. Sies, H. Salleh, "Spray Characteristic of Diesel-Water Injector for Burner System", Advanced Materials and Research Vols. 845 (2014), Trans Tech Publications, Switzerland, pp 66-70.

[9] K. Kannan and M. Udayakumar, "NOx and HC Emission Control Using Water Emulsified Diesel in Single Cylinder Diesel Engine," vol. 4, no. 8, pp. 59-62, 2009.

[10] Amir Khalid, M.D. Anuar, Yusri Ishak, B. Manshoor, Azwan Sapit, Mutalib Leman, Izzuddin Zaman, "Emissions characteristics of small diesel engine fuelled by waste cooking oil", MATEC Web of Conferences, Volume 13, 2014, Article number 06006, DOI: $10.1051 /$ matecconf/20141306006.

[11] Amir Khalid, Keisuke Hayashi, Yoshiyuki Kidoguchi, Tomoaki Yatsufusa, "Effect of air entrainment and oxygen concentration on endothermic and heat recovery process of diesel ignition”, (2011) SAE Technical Papers, DOI: 10.4271/2011-01-1834.

[12] Sáez A. , Flores-Maradiaga A. , Toledo M. , Liquid butane as an alternative fuel for diesel oil burners. Applied Thermal Engineering (2012), doi:0.1016/j.applthermaleng. 2012.04.024, pp 19.

[13] Pedro Benjumea, John Agudelo, Andre's Agudelo (2007). Basic properties of palm oil biodiesel-diesel blends, 87 (2008), pp 2069-2075. 
[14] Yusuf N.N.A.N., Kamarudin S.K., Yaakub Z. (2010). Overview on the current trends in biodiesel production. Energy Conversion and Management, 52 (2011), pp 2741-2751.

[15] Mekhilefa S., Sigaa S., Saidurb R. A review on palm oil biodiesel as a source of renewable fuel. Renewable and Sustainable Energy Reviews 15 (2011), pp 1940-1941.

[16] B. Deepanraj, C. Dhanesh, R. Senthil, M. Kannan, A. Santhoshkumar and P. Lawrence (2011). Use of Palm oil Biodiesel Blends as a Fuel for Compression Ignition Engine, 8 (11), pp 1154-1158.

[17] Venkanna B K, Venkataramana Reddy C. Performance, emission and combustion characteristics of DI diesel engine running on blends of honne oil/diesel fuel/kerosene/DMC. Int J Agric \& Biol Eng, 2011; 4(3): 48 - 57.

[18] P. McCarthy, M.G. Rasul, S. Moazzem (2010). Analysis and comparison of performance and emissions of an internal combustion engine fuelled with petroleum diesel and different biodiesels, 90 (2011), pp 2147-2157.

[19] Pascal Ndayishimiye, Mohand Tazerout (2010). Use of palm oil-based biofuel in the internal combustion engines: Performance and emissions characteristics, 36(2011), pp 1790-1796.

[20] Amir Khalid and Bukhari Manshoor, "Effect of High Swirl Velocity on Mixture Formation and Combustion Process of Diesel Spray", Applied Mechanics and Materials Vols. 229-231 (2012), Trans Tech Publications, Switzerland, pp 695-699

[21] T.F. Yusaf , B.F. Yousif, M.M. Elawad (2010). Crude palm oil fuel for diesel-engines: Experimental and ANN simulation approaches, 36(2011), pp 4871-4878.

[22] T. Leevijit, G. Prateepchaikul (2010). Comparative performance and emissions of IDI-turbo automobile diesel engine operated using degummed, deacidified mixed crude palm oil-diesel blends, 90(2011), pp 1487-1491.

[23] S.S. Wirawan, A.H. Tambunan, M. Djamin, and H. Nabetani. "The Effect of Palm Biodiesel Fuel on the Performance and Emission of the Automotive Diesel Engine". Agricultural Engineering International: the CIGR Ejournal. Manuscript EE 07 005. Vol. X. April, 2008.

[24] Ahmet Necati Ozsezen, Mustafa Canakci, Ali Turkcan, Cenk Sayin (2008). Performance and combustion characteristics of a DI diesel engine fueled with waste palm oil and canola oil methyl esters, 88(2009), pp 629-636.

[25] Pedro Benjumea, John Agudelo, Andre's Agudelo (2008). Effect of altitude and palm oil biodiesel fuelling on the performance and combustion characteristics of a HSDI diesel engine, 88(2009), pp 725-731.

[26] Edward Crabbe, Cirilo Nolasco-Hipolito, Genta Kobayashi, Kenji Sonomoto,Ayaaki Ishizaki (2001). Biodiesel production from crude palm oil and evaluation of butanol extraction and fuel properties, 37(2001), pp 65-71.

[27] Avinash Kumar Agarwal (2006). Biofuels (alcohols and biodiesel) applications as fuels for internal combustion engines, 33 (2007), pp 233-271.

[28] Jawad Nagi, Syed Khaleel Ahmed, Farrukh Nagi (2008). Palm Biodiesel an Alternative Green Renewable Energy for the Energy Demands of the Future, ICCBT 2008 - F - (07) - pp7994.

[29] Jinlin Xuea, Tony E. Grift, Alan C. Hansena (2010). Effect of biodiesel on engine performances and emissions, 15(2011), pp 1098-1116.

[30] T. Leevijit, G. Prateepchaikul (2010). Comparative performance and emissions of IDI-turbo automobile diesel engine operated using degummed, deacidified mixed crude palm oil-diesel blends, 90(2011), pp 1487-1491. 